\title{
The Effects of Summer Sports School Basketball Training on Respiratory Functions of Female Students ${ }^{i}$
}

\author{
Serdar Orhan ${ }^{1, *}$, Canan Gülbin Eskiyecek² \\ ${ }^{1}$ Faculty of Sports Sciences, Firat University, Elazig, Turkey \\ ${ }^{2}$ School of Physical Education and Sports, Mardin Artuklu University, Mardin, Turkey
}

Copyright $\odot 2018$ by authors, all rights reserved. Authors agree that this article remains permanently open access under the terms of the Creative Commons Attribution License 4.0 International License

\begin{abstract}
A total of 60 female students voluntarily participated in this study in which the exercise-dependent changes in the respiratory functions of female students in the age group of 12-16 who participate in basketball training sessions of summer sports school are analysed. 30 female students participated in summer sports school basketball training group constituted the experimental group and 30 female students in the same age group who did not participate in basketball training formed the control group. The experimental group was applied an interval training program specific to basketball 5 days a week in 12 weeks. The control group was not applied any training program at all. Some physical measurements (age, height, weight) and spirometry measurements (FVC, FVC\%, $\mathrm{FEV}_{1}, \mathrm{FEV}_{1} \%, \mathrm{FEV}_{1} / \mathrm{FVC} \%, \mathrm{PEF}, \mathrm{PEF} \%, \mathrm{FEF}_{25 / 75}$, $\mathrm{FEF}_{25 / 75} \%$ ) were recorded as preliminary and post-tests in the research. Paired Simple t-test and Wilcoxon were used in intra-group analyses of data obtained and Mann-Whitney $U$ test was used for the intergroup comparisons. While significant difference can be established in the height, $\mathrm{FVC}, \mathrm{FVC} \%, \mathrm{FEV}_{1}, \mathrm{FEV}_{1} \%$ and $\mathrm{FEV}_{1} / \mathrm{FVC} \%$ values of experimental group and height values of the control group compared to the time before the training; height, weight, $\mathrm{FVC}, \mathrm{FVC} \%$, $\mathrm{FEV}_{1}, \mathrm{PEF}, \mathrm{FEF}_{25 / 75}$ and $\mathrm{FEV}_{1} / \mathrm{FVC} \%$ values of the experimental group have significantly differed from the control group. In conclusion, it can be stated that interval training programs specific to basketball and applied to the female students in summer sports school have positive effects on the respiratory functions and they can contribute to both physical and lung development of individuals.
\end{abstract}

Keywords Respiration, Interval, Female Student, Summer Sports School, Basketball

\section{Introduction}

Summer sports schools are the places where there are sports activities that take place from the end of the previous education term to the beginning of the new educational period, which is also known as the summer holiday period. The main objective is to improve the physical, mental and cognitive characteristics of children through sports activities and training programs. It comes to the agenda in every summer holiday in order to prevent the primary and middle school children from aimlessly spending time at home and to ensure that they learn new things by having fun. Thus, relevant demands of parents and students increase every year and many summer school alternatives appear in metropolitan cities in this regard [5]. Diyarbakir is a metropolitan in qualities; it is located in southeastern Turkey. According to 2017 data, the total population is 1699901 . The female population in the $12-17$ age range is $12.41 \%$ (104564) [39].

Summer sports schools opened within the local governments and municipalities more commonly with the consciousness of being a social state, appeal to all segments of the society for free and non-profit. The sports schools opening within the scope of private sports clubs and in a certain sports branch aren't limited to summer period and they are the profit-oriented organizations mostly that operate all year long, can demand a fee by the popularity of the sports club, aim to incorporate the skilled children in their infrastructure. The third option is the mixed summer schools having the characteristics of both types of summer schools. In other words, they are the sports schools opened by the sports clubs of the local administrations. The summer schools operating most commonly in the current situation are in this classification. The criteria such as the branches offered, the content of the education, the quality of the trainer, the physical conditions and the proximity to the home are among the factors that can be effective in the selection and the benefit of the summer sports school. The main objective of the summer sports schools, regardless of the classification, is to contribute to the physical, mental and cognitive characteristics of children and to identify talented athletes, if any.

It is important to teach the technical skills of sports 
branches to children aged between 11 and 15 in which the skills such as development, learning and comprehension are intensified. Otherwise, it will be very difficult to acquire these skills at later ages [41]. Endurance training for children of this period should include the conditions of especially moving-play and variable continuous load (arranged according to interval principles) [22]. The basketball game requiring constant mobility in which body and intelligence intensify together exhibits motor skills (strength, speed, durability, coordination, etc.) as well as technical skills [41].

Exercise is highly effective on circulatory and respiratory systems. The vital capacity of the lungs is related to the oxygen requirement of the type of sports performed and the body structure of the person. Thoughts about the chronic effects of training on the respiratory system are generally in line with the increase in vital capacity $[7,23]$. Respiratory system adaptation is faster in well-trained people for the increased oxygen requirement during the exercise [18]. However, physical exercise has many positive effects on respiratory functioning systems as it improves aerobic strength and reduces shortness of breath while also improving $\mathrm{VO} 2 \mathrm{max}$, an indication of harmony between the cardiovascular and respiratory systems $[8,10]$.

It has been observed that many countries are trying to create lifelong sport habits to get rid of the sedan lifestyle and overweight. [2]. Sports activities, those played at the childhood ages regularly, play an important role on developing and maintaining healthy and physically good persons. Children, who participates sport activities at the school ages, may adopt sports in their life as a habit when they grow up [26]. Puente and Stringer (2018) reported that the sedentary lifestyle in childhood and adolescence is a major risk factor for obesity and cardiovascular diseases in the later years, and that health can be improved by promoting inclusion in physical activities for all age groups [27].

Studies on the effects of exercise on respiratory parameters in children and adolescents bring about different opinions. The fact that control group does not exist in many of the researches performed to determine to what extent sports affects the respiratory parameters of children and youth and a complete standardization has not been established in terms of respiratory functions yet may cause different opinions in this topic. While some researchers advocate that intense physical exercises increase the respiratory parameters $[4,11,23,24,33,34,42]$, some others state that this development is in parallel with the normal growth totally as the dynamic of age group $[7,12]$. Some other researchers suggest that exercise does not increase respiratory parameters, but also brings them to an efficient and economic condition [3].

Assessing the characteristics of the mechanism of how respiratory parameters are affected from the exercise, it can be expected that sports may increase these parameters in young people without the discrimination of sex. Considering the opinion that the intense physical exercises done by the young people who have not reached their maximum limits of anatomic development accelerate this development, the purpose of this study is to analyse the exercise-dependent changes in the respiratory functions of female students in the age group of 12-16 who participate in basketball training sessions of summer sports school.

\section{Materials and Methods}

\subsection{Subjects}

A total of 60 female students in the age group of 12-16 who participate in the events and organizations held by Bağlar Belediyesi Sports Club in Diyarbakır province within the scope of summer sports schools voluntarily participated in the study. The participant female students did not have a licensed background before the study. The female students and their parents were informed about the study and their written permissions were taken, the students with any health problem or disability were excluded. The study was performed in accordance with the Declaration of Helsinki and the protocol was approved by the Firat University Non-Interventional Research Ethics Committee.

\subsection{Procedure}

The female students who participated in the summer sports school basketball training formed the experimental group. A total of 37 female students participated in basketball exercises. 4 female students were excluded from the research due to the fact that they didn't want to participate in tests after being informed about the study and 3 of them were excluded with the reason that permission of their parents could not be received. So, the experimental group was composed of 30 female students. The other 30 female students in the same age group who participated in other activities (handicrafts, painting, workshop etc.) of the same summer sports school not containing physical activity constituted the control group. The experimental group was applied an interval training program specific to basketball 5 days a week in 12 weeks. The control group was not applied any training program at all.

Some physical measurements; age, height, weight and respiratory functions; forced vital capacity (FVC), the percent of forced vital capacity ( $\mathrm{FVC} \%$ ), forced expiratory volume in first second $\left(\mathrm{FEV}_{1}\right)$, the percent of forced expiratory volume in first second $\left(\mathrm{FEV}_{1} \%\right)$, the ratio of forced expiratory volume in first second to forced vital capacity $\left(\mathrm{FEV}_{1} / \mathrm{FVC} \%\right)$, the peak expiratory flow (PEF), the percent of peak expiratory flow (PEF\%), the forced expiratory flow in $25-75 \%$ of forced vital capacity 
$\left(\mathrm{FEF}_{25 / 75}\right)$, percent of the forced expiratory flow in $25-75 \%$ of forced vital capacity $\left(\mathrm{FEF}_{25 / 75} \%\right)$ values of experimental group and control group were obtained from the athletes in the period of 1 week before and after the beginning of 12-week training program and the change between the preliminary and post-tests were evaluated.

Training Program Applied:

Aim: Interval training with a ball to basketball, Duration of application: 12 weeks, Number of training per week: 5 , Total training number: 60, Method: circuit training, Intensity: moderate-high (for a purpose) Exercise tempo: with a fluent tempo, Application duration of the exercises in the program: 30-45 sec, Duration of break: the incomplete resting principle, Number of serial: 2 set, Break between serials: full break.

Daily training consisted of three parts. Beginning Phase (10 min): Warm-up and opening-streching exercise. Main Phase (40-50 min): Interval training loads were applied 30 $\mathrm{s}$ for the first three weeks, $35 \mathrm{~s}$ for the second three weeks, $40 \mathrm{~s}$ for the third three weeks and $45 \mathrm{~s}$ for the fourth three weeks. While the first week of daily training time of $40 \mathrm{~min}$, after 12 weeks, according to the principle of increasing the load was increased to $50 \mathrm{~min}$. Finishing Phase $(10 \mathrm{~min})$ : Educational games.

Exercises are as follows:

$1^{\text {st }}$ Circuit: Passing to the wall from a distance of 3-4 meters. Chest pass and bounce pass combination.

$2^{\text {nd }}$ Circuit: Continuous lay-up shoot with left and right hand by dribbling. The distance of obstacles from the basket is 5 meters approximately.

$3^{\text {rd }}$ Circuit: Tipping-in the ball to the backboard or circle (both hands).

$4^{\text {th }}$ Circuit: Slalom dribbling, 3 obstacles are consecutively ordered at a distance of 3 meters in a row. Hand is changed in clearing every obstacle while dribbling.

$5^{\text {th }}$ Circuit: Bounce pass. The distance is 3-6 meters on average. It is applied as movement, shoot, rebound, coming back to old position and re-shoot. The failed shoot is tipped-in once in the air.

$6^{\text {th }}$ Circuit: Footwork. A triangle is formed with the obstacles with 4-meter distance between them. Starting from the right, the obstacles are touched with the foot work in the basic position of basketball (it is started from right, left, left or reverse, afterwards) [32].

\subsection{Measurements}

In the experimental and control groups, height measurements of the students were measured in $\mathrm{cm}$ on bare foot by using pharmacy height measure and their body weights were measured in $\mathrm{kg}$ with a pharmacy weighing machine after undressing in a way to leave only shorts and a t-shirt on [36]. Pulmonary function measurements of the students were performed in Diyarbakır Chest Diseases Hospital, SFT laboratory by using a computer-controlled Spirometer device (Chest PC-10) by an expert physician. The students were informed about the application of the test right before the measurements and their personal information (age, height, weight, sex and race) were recorded in spirometer. In the sitting position, the nose was closed with a soft latch and a suitable disposable mouthpiece was placed between the lips and firmly fixed. After 4-5 calm breaths, the individual was asked to take a deep breath and then to evacuate all the air with a difficult, deep and rapid expiration. Measurements were repeated at least 3 times and the best measurement was recorded in $\mathrm{L}$ and $\mathrm{L} / \mathrm{sec}$. [36].

\subsection{Statistical Analysis}

Statistical package program was used in data analysis. Following the normality test, Paired Simple t-test and Wilcoxon were used in determining the preliminary and post-test averages of experimental and control groups and the differences between these averages, Mann-Whitney U test was used for inter-group comparisons. The value of $\mathrm{p}<0.05$ was accepted as the statistical significance level.

\section{Results}

Average age of the participant experimental group is $13.033 \pm 0.964$ and the average age of the control group is $13.033 \pm 0.961$.

While statistically significant difference was found in the height, $\mathrm{FVC}, \mathrm{FVC} \%, \mathrm{FEV}_{1}, \mathrm{FEV}_{1} \%$ and $\mathrm{FEV}_{1} / \mathrm{FVC} \%$ variables of the experimental group before and after the training $(\mathrm{p}<0.05)$, no significant difference was found in other variables $(p>0.05)$. While statistically significant difference was found in the height variable of the control group before and after the training $(p<0.05)$, no significant difference was found in other variables $(\mathrm{p}>0.05)$. 
Table 1. Comparison of Some Physical and Respiratory Values of Experimental and Control Group Before and After the Training

\begin{tabular}{|c|c|c|c|c|c|c|c|}
\hline Variables & Measurements & $\begin{array}{l}\text { Experimental Group } \\
\text { (EG) } n=30\end{array}$ & $\mathbf{t}$ & $\mathbf{p}$ & $\begin{array}{l}\text { Control Group } \\
\text { (CG) } n=30\end{array}$ & $\mathbf{t}$ & $\mathbf{p}$ \\
\hline \multirow{2}{*}{ Height (cm) } & Pre-Test & $1.568 \pm 0.077$ & \multirow{2}{*}{-7.426} & \multirow{2}{*}{$.000^{*}$} & $1.463 \pm 0.066$ & \multirow{2}{*}{-2.693} & \multirow{2}{*}{$.012^{*}$} \\
\hline & Post-Test & $1.583 \pm 0.074$ & & & $1.465 \pm 0.067$ & & \\
\hline \multirow{2}{*}{ Weight (kg) } & Pre-Test & $48.350 \pm 8.374$ & \multirow{2}{*}{-1.200} & \multirow{2}{*}{.240} & $39.433 \pm 7.669$ & \multirow{2}{*}{-1.613} & \multirow{2}{*}{.118} \\
\hline & Post-Test & $48.867 \pm 7.977$ & & & $39.800 \pm 7.680$ & & \\
\hline \multirow{2}{*}{$\mathrm{FVC}(\mathrm{L})$} & Pre-Test & $2.736 \pm 0.411$ & \multirow{2}{*}{-7.213} & \multirow{2}{*}{$.000^{*}$} & $2.359 \pm 0.420$ & \multirow{2}{*}{-1.879} & \multirow{2}{*}{.070} \\
\hline & Post-Test & $3.029 \pm 0.449$ & & & $2.412 \pm 0.444$ & & \\
\hline \multirow{2}{*}{$\mathrm{FVC} \%$} & Pre-Test & $88.367 \pm 8.584$ & \multirow{2}{*}{-5.988} & \multirow{2}{*}{$.000^{*}$} & $90.067 \pm 11.444$ & \multirow{2}{*}{-1.717} & \multirow{2}{*}{.097} \\
\hline & Post-Test & $98.933 \pm 11.724$ & & & $91.400 \pm 11.349$ & & \\
\hline \multirow{2}{*}{$\mathrm{FEV}_{1}(\mathrm{~L})$} & Pre-Test & $2.623 \pm 0.388$ & \multirow{2}{*}{-3.002} & \multirow{2}{*}{$.005^{*}$} & $2.265 \pm 0.419$ & \multirow{2}{*}{-1.698} & \multirow{2}{*}{.100} \\
\hline & Post-Test & $2.767 \pm 0.363$ & & & $2.281 \pm 0.423$ & & \\
\hline \multirow{2}{*}{$\mathrm{FEV}_{1} \%$} & Pre-Test & $95.733 \pm 9.759$ & \multirow{2}{*}{-3.660} & \multirow{2}{*}{$.001 *$} & $99.600 \pm 13.056$ & \multirow{2}{*}{-1.204} & \multirow{2}{*}{.238} \\
\hline & Post-Test & $102.668 \pm 10.456$ & & & $100.267 \pm 12.733$ & & \\
\hline \multirow{2}{*}{$\mathrm{PEF}(\mathrm{L} / \mathrm{sec})$} & Pre-Test & $5.279 \pm 0.842$ & \multirow{2}{*}{0.166} & \multirow{2}{*}{.870} & $4.736 \pm 0.964$ & -0828 & 414 \\
\hline & Post-Test & $5.253 \pm 0.980$ & & & $4.742 \pm 0.949$ & $-0.8<8$ & .414 \\
\hline PFF \% & Pre-Test & $88.467 \pm 12.719$ & 501 & & $90.833 \pm 16.828$ & 1363 & \\
\hline РEF \% & Post-Test & $89.867 \pm 17.916$ & -0.501 & .620 & $91.200 \pm 16.312$ & -1.363 & 183 \\
\hline $\mathrm{FFF}_{2}(\mathrm{~L} / \mathrm{sec})$ & Pre-Test & $3.680 \pm 0.762$ & 1294 & 206 & $3.297 \pm 0.705$ & -0.958 & 346 \\
\hline $\mathrm{FEF}_{25 / 75}(\mathrm{~L} / \mathrm{sec})$ & Post-Test & $3.532 \pm 0.699$ & 1.294 & .206 & $3.312 \pm 0.704$ & -0.958 & .346 \\
\hline $\mathrm{FFF}_{2} \%$ & Pre-Test & $110.333 \pm 21.379$ & & & $115.767 \pm 23.535$ & & \\
\hline $\mathrm{FEF}_{25 / 75} \%$ & Post-Test & $109.100 \pm 21.655$ & 0.349 & .730 & $114.533 \pm 24.790$ & 1.003 & .324 \\
\hline & & & & & & $\mathrm{Z}$ & $\mathrm{p}$ \\
\hline & Pre-Test & $96.097 \pm 5.257$ & 4324 & 000 * & $97.510 \pm 2.732$ & & \\
\hline $\mathrm{FEV} / \mathrm{FVC} \%$ & Post-Test & $91.150 \pm 6.725$ & 4.324 & $.000^{*}$ & $97.260 \pm 2.999$ & -0.536 & .592 \\
\hline
\end{tabular}

$* \mathrm{p}<0.05$

Table 2. Inter-group Comparison of Some Physical and Respiratory Values of Experimental and Control Group Before and After the Training

\begin{tabular}{|c|c|c|c|c|c|}
\hline Variables & Measurements & $\begin{array}{l}\text { Experimental Group } \\
\text { (DG) } n=30\end{array}$ & $\begin{array}{l}\text { Control Group } \\
\text { (KG) } \mathbf{n}=\mathbf{3 0}\end{array}$ & $\mathbf{t}$ & $\mathbf{p}$ \\
\hline \multirow{2}{*}{ Age (years) } & Pre-Test & $13.033 \pm 0.964$ & $13.030 \pm 0.961$ & -0.987 & .759 \\
\hline & Post-Test & & & & \\
\hline \multirow{2}{*}{ Height (cm) } & Pre-Test & $1.568 \pm 0.077$ & $1.463 \pm 0.066$ & 5.653 & $.000^{*}$ \\
\hline & Post-Test & $1.583 \pm 0.074$ & $1.465 \pm 0.067$ & 6.489 & $.000 *$ \\
\hline \multirow{2}{*}{ Weight (kg) } & Pre-Test & $48.350 \pm 8.374$ & $39.433 \pm 7.669$ & 4.301 & $.000 *$ \\
\hline & Post-Test & $48.867 \pm 7.977$ & $39.800 \pm 7.680$ & 4.484 & $.000 *$ \\
\hline \multirow{2}{*}{ FVC (L) } & Pre-Test & $2.736 \pm 0.411$ & $2.359 \pm 0.420$ & 3.512 & $.001 *$ \\
\hline & Post-Test & $3.029 \pm 0.449$ & $2.412 \pm 0.444$ & 5.350 & $.000 *$ \\
\hline \multirow{2}{*}{ FVC \% } & Pre-Test & $88.367 \pm 8.584$ & $90.067 \pm 11.444$ & -0.651 & .518 \\
\hline & Post-Test & $98.933 \pm 11.724$ & $91.400 \pm 11.349$ & 2.529 & $.014 *$ \\
\hline \multirow{2}{*}{$\mathrm{FEV}_{1}(\mathrm{~L})$} & Pre-Test & $2.623 \pm 0.388$ & $2.265 \pm 0.419$ & 3.439 & $.001 *$ \\
\hline & Post-Test & $2.767 \pm 0.363$ & $2.281 \pm 0.423$ & 4.769 & $.000^{*}$ \\
\hline \multirow{2}{*}{$\mathrm{FEV}_{1} \%$} & Pre-Test & $95.733 \pm 9.759$ & $99.600 \pm 13.056$ & -1.299 & .199 \\
\hline & Post-Test & $102.668 \pm 10.456$ & $100.267 \pm 12.733$ & 0.798 & .428 \\
\hline \multirow{2}{*}{ PEF (L/sec) } & Pre-Test & $5.279 \pm 0.842$ & $4.736 \pm 0.964$ & 2.325 & $.024 *$ \\
\hline & Post-Test & $5.253 \pm 0.980$ & $4.742 \pm 0.949$ & 2.053 & $.045^{*}$ \\
\hline \multirow{2}{*}{ PEF \% } & Pre-Test & $88.467 \pm 12.719$ & $90.833 \pm 16.828$ & -0.615 & .541 \\
\hline & Post-Test & $89.867 \pm 17.916$ & $91.200 \pm 16.312$ & -0.301 & .764 \\
\hline \multirow{2}{*}{$\mathrm{FEF}_{25 / 75}(\mathrm{~L} / \mathrm{sec})$} & Pre-Test & $3.680 \pm 0.762$ & $3.297 \pm 0.705$ & 2.022 & $.048^{*}$ \\
\hline & Post-Test & $3.532 \pm 0.699$ & $3.312 \pm 0.704$ & 1.214 & .230 \\
\hline \multirow{3}{*}{$\mathrm{FEF}_{25 / 75} \%$} & Pre-Test & $110.333 \pm 21.379$ & $115.767 \pm 23.535$ & -0.936 & .353 \\
\hline & Post-Test & $109.100 \pm 21.655$ & $114.533 \pm 24.790$ & -0.904 & .370 \\
\hline & & & & $\mathrm{Z}$ & $\mathrm{p}$ \\
\hline \multirow{2}{*}{$\mathrm{FEV}_{1} / \mathrm{FVC} \%$} & Pre-Test & $96.097 \pm 5.257$ & $97.510 \pm 2.732$ & -0.673 & .501 \\
\hline & Post-Test & $91.150 \pm 6.725$ & $97.260 \pm 2.999$ & -3.740 & $.000^{*}$ \\
\hline
\end{tabular}


While statistically significant difference was found in the height, weight, $\mathrm{FVC}, \mathrm{FVC} \%, \mathrm{FEV}_{1}, \mathrm{PEF}, \mathrm{FEF}_{25 / 75}$ and $\mathrm{FEV}_{1} / \mathrm{FVC} \%$ variables of the experimental and control group before and after the training $(\mathrm{p}<0.05)$, no significant difference was found in other variables $(p>0.05)$.

\section{Discussion}

The fact that the significant increase in the height measurements of the study is seen in both of the experimental and control groups can be explained with the ordinary physical development of the participant students. As a matter of fact as stated by Özer and Özer, this situation can be a natural result of not entering into the last period of adolescence between the ages of 18-20 which is a period in which increase in length stops. It has been stated that children make rapid development in terms of height values until the end of adolescence [25]. Triki et al. (2013) found that there was a significant relationship between height and FVC, FEV1 values in the pre-pubertal boys [38]. In the study of Günden (2006) analysing the lung capacities of females aged between 10 and 19 , it has been stated that those doing sports are taller and have larger lung capacity than the individuals not doing sports [13]. On the other hand, it is thought that the significant difference in body weight in factor of the experimental group arises from the nonhomogeneous distribution. Since the body weights of the students in the experimental group were also high at the beginning of the study.

The increase in $\mathrm{FVC}, \mathrm{FVC} \%, \mathrm{FEV}_{1}, \mathrm{FEV}_{1} \%$ and $\mathrm{FEV}_{1} / \mathrm{FVC} \%$ values of female students participating in basketball training was significant compared to the time before the training. It was observed after the training that the increase in weight, $\mathrm{FVC}, \mathrm{FVC} \%, \mathrm{FEV}_{1}, \mathrm{PEF}$ and $\mathrm{FEV}_{1} / \mathrm{FVC} \%$ values of experimental group was significant compared to the control group. This suggests that the respiratory muscles are strengthened by the effect of training [1,30], and it causes high level of the forced vital capacity together with the increase in vital capacity [6]. Lazovic et al. (2015) reported that respiratory adaptations occurred with participation in sports activities and these adaptations changed according to the type of activity [16]. Therefore, participation in certain physical activities or sports may lead to the strengthening of respiratory muscles, improvements in pulmonary functions, and achieving an effective pulmonary function $\left(\mathrm{FVC}, \mathrm{FEV}_{1}\right)$ [17]. In addition, it has been reported that aerobic power is positively associated with lung volumes and it has been reported that lung volumes and capacities increase with participation in sportive activities at early ages $[14,28]$.

When the respiratory function parameters of 12-weeks were examined in study, significant improvements were observed in the FVC and $\mathrm{FEV}_{1}$ values of experimental group $(p<0.05)$. This may have been due to increased values of $\mathrm{FVC}$ and $\mathrm{FEV}_{1}$, as regular 12-week aerobic and strength exercise programs are long enough to cause significant changes in lung function. Different exercises, such as interval and highintensity training programs, have shown that they can increase pulmonary respiratory functions (FVC and $\mathrm{FEV}_{1}$ ) [21]. Melekoğlu et al. (2018) has informed that regular training in childhood and adolescence enhances lung volumes and functions [19].

Thus, it can be stated in this study that the strength of diaphragm muscle and respiratory muscles has increased in parallel to the increase in FVC values. The fact that the respiratory values of the female students who participate in basketball training are significant compared to the pre-training time can be considered as an indicator of the effectiveness of their activities.

In previously performed similar studies, it is stated that the increase in $\mathrm{FVC}$ and $\mathrm{FEV}_{1}$ values of male children aged 12-14 who do regular exercise is significant compared to the pre-training period [35], FVC values in young females aged 16 are higher in the athletes doing athletics compared to the control group [20], $\mathrm{VC}, \mathrm{FVC}, \mathrm{FEV}_{1}$ and $\mathrm{MVV}$ values of female students aged between 11 and 14 playing volleyball are higher than those not doing sports [26], the FVC, FEV1, MVV ratio were higher in athletes than in the normal sedentary control individuals $[4,15,29,40]$, the PEF and $\mathrm{FEF}_{25 / 75}$ values of the training program applied for 3 months on the sedentary children in the age group of 10-16 are significant compared to the pre-training period [37] and in similar studies performed on children athletes in different branches, it is stated that PEF and $\mathrm{FEF}_{25 / 75}$ values significantly differ after the exercise [3,9].

In the study of Günden (2006) analysing the lung capacities of women aged between 10 and 19 , it has been concluded that the respiratory function tests all of the individuals doing sports are higher than those not doing sports without age group and gender discrimination [13]. Similarly Savucu et al. (2012) has informed that respiratory values of female handball players were found significantly than those not doing sports [31].

There are also other researches not in accordance with the literature. Taşgın and Dönmez (2009) have determined that the 3-month training program applied to the sedentary children in the age group of 10-16 does not have any effect on FVC and $\mathrm{FEV}_{1}$ values [37]. Similarly FVC, FEV1, PEF and FEV1/FVC values were compared between group of athletes engaged in different sport training and it was demonstrated that there were no significant differences between groups (wrestling vs. basketball, football vs. badminton, football vs. judo) [38].

In literature, there are studies revealing that the effects of training programs performed on individuals who have not yet completed their development have a positive effect on respiratory functions while there are also reverse studies $[3,7,12,37]$. It should be considered that physiological development can be more effective on the respiratory parameters of children than the exercise [3].

This study bears some limitations. The study is limited 
to the female students in the age group of 12-16 in Diyarbakır province. In order to determine the role of age and sex in adolescence, male students and older or younger students can be preferred. Another limitation is the duration of exercise. Extending the study into a whole year and applying it to larger sample groups can make maximum contribution to the follow-up of anatomical and physiological changes and development.

\section{Conclusions}

In conclusion, it can be stated that 12-week interval training specific to basketball and applied to the female students in summer sports schools has some positive effects on physical and respiratory functions and it can contribute to the physical and lung development of individuals. Therefore this study suggest that sports activity and training may cause an increase in the respiratory functions which could be due to increased development of respiratory musculature incidental to physical training or exercise.

Furthermore, the sports activities that children do regularly before and after the puberty can affect the development of a healthy physical structure, enable the acquisition of habits that can be sustained in adulthood and ensure determining the individuals who can be performance athletes.

\section{Acknowledgements}

The authors thank all female students for their participation. In addition, thanks to the contributions of Diyarbakır Chest Diseases Hospital SFT laboratory for pulmonary function measurements.

\section{Conflicts of Interest}

The authors declare no conflict of interest.

\section{Funding}

This research received no external funding.

\section{REFERENCES}

[1] Akhade, V.V., Muniyappanavar, N.S. Evaluation of pulmonary function in sportsmen playing different games. Natl J Physiol Pharm Pharmacol, 2017; 7(10):1091-1094. DOI: 10.5455/njppp.2017.7.0516023052017

[2] Akyol, B., Söğüt, K. Investigation of cardiovascular endurance levels of sedentary high school students, Journal of Education and Training Studies, 2018: 6(5), 144-151. DOI:10.11114/jets.v6i5.3039

[3] Atabek, H.Ç. Investigation of some pulmonary functions and bio-motoric properties in 15-17 aged group of students engaged in different sports, Inonu University Journal of Physical Education and Sport Sciences, 2015: 2(1), 1-16.

[4] Atan, T., Akyol, P., Çebi, M. Comparison of respiratory functions of athletes engaged in different individual sports branches, Dicle Medical Journal, 2013: 40(2): 192-198. DOI: $10.5798 /$ diclemedj.0921.2013.02.0253

[5] Ayhan, M.B. An integrated hesitant fuzzy AHP and TOPSIS approach for selecting summer sport school. Sakarya University Journal of Science, 2018: 22(2), 269-284. DOI:10.16984/saufenbilder.306664

[6] Çiçek, G., Güllü, A., Güllü, E., Yamaner, F. The effect of aerobic and core exercises on forced vital capacity, Physical Culture and Sport. Studies and Research, 2018: 77(1), 41-47. DOI: https://doi.org/10.2478/pcssr-2018-0005

[7] Demirhan, B., Abdırahmanova, D., Canuzakov, K., Geri, S. Evaluation of some respiratory functions of Kyrgyz National Team Athletes before 2016 Summer Olympic Games, Journal of Human Sciences, 2018: 15(3), 17111716. DOİ:10.14687/jhs.v15i3.5431

[8] Doijad, V.P., Kample, P., Surdi, A.D. Effect of yogic exercises on aerobic capacity (VO2 max). International Journal of Recent Trends in Science and Technology, 2013: 6(3), 119-121.

[9] Dokumac1, B., Atabek, H.Ç. Relationship between anthropometric variables, respiratory function and bio-motoric properties in Turkish flat water canoe athletes, International Journal of Social Sciences and Education Research, 2015: 1(3), 758-765.

[10] Fatima, S.S., Rehman, R., Saifullah Khan, Y. Physical activity and its effect on forced expiratory volume. J Pak Med Assoc, 2013: 63(3), 310-312. PMID: 23914626

[11] Gaurav, V., Singh, A. Respiratory functions of volleyball players according to specific playing positions, International Journal of Physical Education Fitness and Sports, 2013: 2 (3), 45-49.

[12] Grisbrook, T.L., Wallman, K.E., Elliott, C.M., Wood, F.M., Edgar, D.W., Reid, S.L. The effect of exercise training on pulmonary function and aerobic capacity in adults with burn. Burns, 2012: 38 (4), 607-613.

[13] Günden, İ.E. Spor Yapan Bireyler ile Spor Yapmayan Bireylerin Kardiyo Torasik Endekslerinin, Akciğer Alan Kapasitelerinin ve Solunum Fonksiyon Testlerinin Karşılaştırılması, PhD Thesis, Atatürk University Institute of Health Sciences, Department of Physical Education and Sports, Erzurum, 2006.

[14] Hancox, R. J., Rasmussen, F. Does physical fitness enhance lung function in children and young adults? European Respiratory Journal, 2018: 51(2), 1701374. DOI: $10.1183 / 13993003.01374-2017$

[15] Indira Devi, C., Maruthi, W. Comparative study of pulmonary function tests in sedentary individuals and dynamic exercising people. J Pharmagy Biological Sci, 2015: 10, 73-77. DOI: 10.9790/3008-10337377 
[16] Lazovic, B., Mazic, S., Suzic-Lazic, J., Djelic, M., Djordjevic-Saranovic, S., Durmic, T., Zikic, D., Zugic, V. Respiratory adaptations in different types of sport. Eur Rev Med Pharmacol Sci, 2015: 19(12), 2269-2274. PMID: 26166653

[17] Mahotra, N.B., Amatya, T.M., Rana, B.S., Banstola, D. Effects of exercise on pulmonary function tests: A comparative study between athletes and non-athletes in Nepalese settings. Journal of Chitwan Medical College, 2016: 6(1), 2123. DOI:http://dx.doi.org/10.3126/jcmc.v6il. 16575

[18] Marangoz, I., Aktug, Z.B., Celenk, C., Top, E., Eroglu, H., Akil, M. The comparison of the pulmonary functions of the individuals having regular exercises and sedentary individuals. Biomedical Research, 2016; 27 (2): 357-359.

[19] Melekoğlu, T., Işın, A., Ünlü, G. Antrenmanın 13-14 yaş adölesanlarda solunum sistemi üzerine etkileri. Ulusal Spor Bilimleri Dergisi, 2018: 2 (1), 1-7. DOI: 10.30769/usbd.414833

[20] Moğulkoç, R., Baltacı, A., Keleştimur, K. Koç, H, Özdemirli, S. 16 yaş grubu sporcu genç kızlarda max vo2 ve bazı solunum parametreleri üzerine bir araştırma, Gazi BESBD, 1997: 2(1), 11-18.

[21] Moradians, V., Rahimi, A., Javad Moosavi, S.A., Sahebkar Khorasani, F.S., Mazaherinejad, A., Mortezazade, M., Raji, H. Effect of eight-week aerobic, resistive, and interval exercise routines on respiratory parameters in non-athlete women. Tanaffos, 2016: 15(2), 96-100. PMID:27904541

[22] Muratl1, S. Çocuk ve spor, Geliştirilmiş 3. Bask1, Nobel Yayın, Ankara, 2013.

[23] Ocak, Y., Savas, S., Isik, O., Ersoz, Y. The effect of eight-week workout specific to basketball on some physical and physiological parameters. Procedia-Social and Behavioral Sciences, 2014: 152, 1288-1292.

[24] Özdal, M., Dağlıoğlu, Ö., Demir, T., Özkul, N. Effect of aerobic exercise on arterial hemoglobin oxygen saturation. Sports and Performance Research Journal, 2014: 5(1), 27-34.

[25] Özer, D.S., Özer, M.K. Çocuklarda Motor Gelişim, Kazanc1 Matbaacılık Inc., İstanbul, 2000.

[26] Özveren, Y., Özçaldıran, B, Oral, O. Examining effects of volleyball trainings on some respiration and circulation parameters of 11-14 years old female test subjects, International Journal of Science Culture and Sport, 2015: 2 (Special Issue 2), 234-241. DOI: 10.14486/IJSCS195

[27] Puente-Maestu, L., Stringer, W.W. Physical activity to improve health: do not forget that the lungs benefit too, European Respiratory Journal, 2018: 51: 1702468. DOI: $10.1183 / 13993003.02468-2017$

[28] Rasmussen, F., Hancox, B. (2013). The effects of physical fitness on lung function from childhood to adulthood-The Odense schoolchild study, European Respiratory Society (ERS) 2013 Annual Congress. Barcelona, Spain, September $07-11,2013$.

[29] Rosemary Peter, Sood S, Dhawan A. A comparative evaluation of pulmonary functions in athletes, yogis and sedentary individuals. Int J Basic Appl Physiol, 2013; 2: 127-131.
[30] Savucu, Y. Influence of 12-week training on aerobic capacity and respiratory functions of adolescents with down syndrome, World Applied Sciences Journal, 2010: 11(10), 1292-1296.

[31] Savucu, Y., Arslan, C., Gacar, A., Karadağ, A., Biçer, Y.S., Gür, E. Evaluation of respiratory and echocardiography parameters in young female handball players, African Journal of Microbiology Research, 2012: 6(16), 3744-3748. DOI: $10.5897 / A J M R 12.254$

[32] Sevim, Y. Basketbol Teknik-Taktik-Antrenman. Fil Yayınevi, Ankara, 2010.

[33] Sharma, M., Acharya, A. Effect of yogic exercise on oxygen satüration level in chronic smokers. International Journal of Scientific Research, 2018: 7(1), 1-2.

[34] Surwase, S.P., Deore, D.N., Pallod, K.G., Khan, S.T. Comparative study of aerobic and anaerobic power in football players and control group. IOSR Journal of Dental and Medical Sciences, 2015: 14 (5): 53-56. DOI: 10.1080/09720073.2014.11891969

[35] Şahin, O. Düzenli Egzersiz Eğitiminin 12-14 Yaş Cocukların Bazı Fiziksel ve Fizyolojik Parametreleri Üzerine Etkisinin İncelenmesi, Master's Thesis, Selçuk University Institute of Health Sciences, Department of Physical Education and Sports, Konya: 2007.

[36] Günay, M., Tamer, K., Cicioğlu, İ., Şıtar, E. Spor Fizyolojisi ve Performans Ölçüm Testleri, Gazi Kitabevi, Ankara, 2018.

[37] Taşgın, E., Dönmez, N. The effect of the exercise program applied the children between 10 and 16 ages on the parameters of respiratory, Selçuk University Journal of Physical Education and Sport Science, 2009: 11(2), 13-16.

[38] Triki, M., Rebai, H., Shamssain, M., Masmoudi, K., Fellmann, N., Zouari, H., Tabka, Z. Comparative study of aerobic performance between Football and Judo Groups in Prepubertal boys. Asian journal of sports medicine, 2013: (3), 165-174.

[39] Turkish Statistical Institute (TurkStat). The Results of Address Based Population Registration System, 2017. Online available from http://www.turkstat.gov.tr/PreTa blo.do?alt_id=1059

[40] Vedala, S., Paul, N., Mane, A.B. Differences in pulmonary function test among athletic and sedentary population. Natl J Physiol Pharm Pharmacol 2013; 3: 118-123.

[41] Yazarer, İ., Taşmektepligil, M.Y., Ağaoğlu, Y.S., Ağaoğlu, S.A., Albay, F., Eker, H. Yaz Spor Okullarında Basketbol Çalışmalarına Katılan Grupların İki Aylık Gelişmelerinin Fiziksel Yönden Değerlendirilmesi, Spormetre Beden Eğitimi ve Spor Bilimleri Dergisi, 2004: 2(4), 163-170. DOI:10.1501/Sporm_0000000042

[42] Yiğit, T., Kolukısa, Ş., Aydoğan, A. Investigation of the physiological changes of women performing sports for recreational purposes. Sport and Performance Research Journal, 2013: 4 (1), 17-22.

\footnotetext{
'This study was summarized from the master's thesis.
} 